\section{B A Institute of \\ YK Business Administration \\ 六下 \\ Karachi \\ Leadership and Ideas for Tomorrow}

Business Review

Volume 8 Issue 1 January-June 2013

$1-1-2013$

\title{
Lucky cement: A price leader in the Karachi Stock Exchange due to their marketing breakthrough in to the South Asian Markets
}

Aman U. Saiyed

Institute of Business Administration, Karachi

Muhammad Asadullah

Manager Export Marketing, Lucky Cement

Follow this and additional works at: https://ir.iba.edu.pk/businessreview

Part of the Corporate Finance Commons, and the Marketing Commons

\section{cc) (i)}

This work is licensed under a Creative Commons Attribution 4.0 International License.

\section{Recommended Citation}

Saiyed, A. U., \& Asadullah, M. (2013). Lucky cement: A price leader in the Karachi Stock Exchange due to their marketing breakthrough in to the South Asian Markets. Business Review, 8(1), 149-159. Retrieved from https://doi.org/10.54784/1990-6587.1222 
https://ir.iba.edu.pk/businessreview/vol8/iss1/11

DOI: https://doi.org/10.54784/1990-6587.1222

Business Review - Volume 8 Number 1

January - June 2013

\title{
CASE STUDY
}

\section{Lucky Cement A Price Leader in the Karachi Stock Exchange due to their Marketing Break through in to the South Asian Markets}

\author{
Aman U. Saiyed \\ Institute of Business Administration, Karachi \\ Muhammad Asadullah \\ Manager Export Marketing, Lucky Cement
}

\begin{abstract}
Cement is one of the most significant commodities in the area of physical development of infrastructure. As the South Asian economies develop and more and more demands are made on the infrastructure, cement will emerge as the key marketable commodity in this part of the world.

In the past 10 years the cement industry in Pakistan added capacity at a rapid pace. They made large profits on the back of high demand. Lately, they have experienced decline in sales and profits. To avoid the volatility of the domestic markets, some cement manufacturers have looked overseas. Lucky Cement Limited, as one of the leading manufactures, therefore decided to build a facility in the south to:

- $\quad$ Meet the growing needs of the southern part of the country, and

- $\quad$ To export the surplus to the Middle East, Africa and South Asia. Currently, the maritime trade towards Europe and the US is experiencing a slow down. This has created a huge buildup of containers in Asia. Lucky is using this buildup of containers to their advantage. They lease the containers at a reduced rate to ship cement to India and Sri Lanka. They also used a unique approach to meet the time-consuming quality approval process by using a UK based quality appraisal agency to save the approval time. By using the shipping cost advantage and shortening the approval time in, Lucky Cement has created a strong presence in both India and Sri Lanka.
\end{abstract}

\section{Introduction}

On May $3^{\text {rd }}, 2013$ Lucky Cements shares closed at Rs. 173.89. This is a great turnaround for a company whose shares were being traded at Rs. 62.14 on June $30^{\text {th }}, 2010$. Their earnings per share have gone up from Rs. 7.35 in 2006 to Rs. 12.28 in 2011. This positive change was a result of the company's sustained effort to expand their sales and lower the cost of production. Another major aspect of this change was a marketing breakthrough for Lucky. They opened the export market swelling cement to the South Asian countries. Although Lucky has been selling cement to Afghanistan for a long time, they entered the Indian and Sri Lankan market after they opened their production facility in Nooriabad and selling bulk cement through Port Qasim to India and Sri 
Lanka. Their continued profitability and high dividend payment have made them a darling of investors of Karachi Stock Exchange. Cement is one of the most significant commodities in the area of physical development of infrastructure. As the South Asian economies develop and more and more demands are made on the infrastructure, cement will emerge as the key marketable commodity in this part of the world.

The story of cement industry is as old as the story of industrial development in this part of the subcontinent. The first cement plant was established at Wah in 1921. On the eve of independence, there were four cement plants operating in Pakistan with a total manufacturing capacity of 470,000 tons per year. Pakistan Industrial Development Corporation established two new cement plants in 1956. As the newly independent country started development of physical infrastructure more cement plants were established to meet the increasing demand.

The expansion of cement industry took a big hit when it was nationalized in 1972. A new government organization, State Cement Corporation was created and ten plants with the annual capacity of 2.8 million tons plants were transferred to it. For the next 12 years, the industry worked under strict government regulation and price controls. State Commission of Pakistan added five new cement plants with the annual capacity of 1.8 million tons. In 1985, the government started to deregulate the controls and pricing structure. The government also started encouraging the private sector to build cement plants to meet the growing needs of the country. In 1991 a process of denationalization started. This encouraged the private sector to become active and built seven new plants ${ }^{1}$.

In the past 10 years the industry has added capacity at a rapid pace. New plants have come on stream and the old plants have added more manufacturing capacity. As on November 2011, the two zones had an installed capacity of 42 million tons of clinker and 44 million tons of cement. The break down by zones is as follows ${ }^{2}$ :

Table-1

\begin{tabular}{|l|r|r|}
\hline & \multicolumn{2}{|c|}{$\begin{array}{c}\text { Annual Installed Capacity } \\
\text { (Millions of tons) }\end{array}$} \\
\hline & Clinker & \multicolumn{2}{c|}{ Cement } \\
\hline North Zone & $35,382,857$ & $37,152,000$ \\
\hline South Zones & $6,728,571$ & $7,065,000$ \\
\hline Total & $42,111,428$ & $44,217,000$ \\
\hline
\end{tabular}

One of the significant aspects of cement industry is that not all the manufacturers are making money. It is a high investment business where fixed costs are extremely high. The cement business therefore, relies heavily on working at full capacity. The industry as a whole was not very profitable in the 90s. The decade of 2000 saw rapid development of infrastructure in Pakistan. Some of the major projects undertaken during this period are the building of Gwadar port, and the Makran coastal highway in Baluchistan, building of motorway in Punjab and Khyber Pakhtunkhwa, lining of water courses in Punjab and Sindh and construction of new houses and commercial building all over the country. 
There has been a marked change in the profitability of business from 1990s to 2000s. The early months of 2000 saw the industry as a whole making with 2003-4 being a banner year for them. Their fortunes turned in 2007-8 when the industry cumulatively made a loss of 6.22 billion rupees. An idea of how the fortunes of the industry fluctuate between stout years and lean years can be had by looking at the following table ${ }^{3}$ :

Table - 2

\begin{tabular}{|c|r|r|r|}
\hline & \multicolumn{2}{|c|}{ Profit } & \multicolumn{2}{c|}{$\begin{array}{c}\text { Loss } \\
\text { (loss) }\end{array}$} \\
\hline Financial Year & \multicolumn{3}{|c|}{ (Billions of Rupees) } \\
\hline $2010-2011$ & 5.98 & $(5.27)$ & 0.71 \\
\hline $2009-2010$ & 4.84 & $(13.60)$ & $(8.76)$ \\
\hline $2008-2009$ & 10.32 & $(4.95)$ & 5.37 \\
\hline $2007-2008$ & 3.30 & $(9.52)$ & $(6.22)$ \\
\hline $2006-2007$ & 5.57 & $(3.71)$ & 1.86 \\
\hline $2005-2006$ & 17.74 & $(0.41)$ & 17.33 \\
\hline $2004-2005$ & 10.18 & $(0.39)$ & 9.79 \\
\hline $2003-2004$ & 6.17 & $(0.94)$ & 5.23 \\
\hline $2002-2003$ & 0.80 & $(1.93)$ & $(1.13)$ \\
\hline $2001-2002$ & 1.55 & $(3.14)$ & 0.03 \\
\hline $2000-2001$ & 0.66 & $(1.43)$ & $(2.48)$ \\
\hline $1999-2000$ & 1.12 & $(3.96)$ & $(3.77)$ \\
\hline $1998-1999$ & 0.19 & & \\
\hline
\end{tabular}

To avoid this fluctuation between profit and loss and to diversify their markets, Pakistani cement makers began to look at the export markets. After post 9/11 development work taking off in Afghanistan and high oil process leading to more construction work in the Middle East, Pakistani cement makers found good export markets at both places. The industry heavily exported to these two markets in the early part of 2000. As a matter of fact, bulk of Pakistani cement was exported to Afghanistan with the North Zone doing most of the exporting.

Afghanistan has been a traditional export market for Pakistani cement makers. The export procedures a resample, transportation is invariably by land and the exporters have long term contacts with Afghani importers. Manufacturers from the North Zone therefore, have always exported their surplus to Afghanistan. It is after the business activity slackened in Pakistan and the cement manufacturers started building a surplus that they started eyeing other destinations for their product. The table below shows the changing emphasis of Pakistani cement exporters ${ }^{4}$ : 
Table -3

\begin{tabular}{|c|c|c|c|c|c|r|r|}
\hline $\begin{array}{c}\text { Financi } \\
\text { al } \\
\text { Year }\end{array}$ & $\begin{array}{c}\text { Export to } \\
\text { Afghanistan } \\
\text { Cement }\end{array}$ & $\begin{array}{c}\text { Export } \\
\text { to } \\
\text { India } \\
\text { Cement }\end{array}$ & $\begin{array}{c}\text { Export to } \\
\text { Others } \\
\text { Cement }\end{array}$ & $\begin{array}{c}\text { Export to } \\
\text { Others } \\
\text { Clinker }\end{array}$ & $\begin{array}{c}\text { Total } \\
\text { Exports }\end{array}$ & $\begin{array}{c}\text { North } \\
\text { Zone }\end{array}$ & $\begin{array}{c}\text { South } \\
\text { Zone }\end{array}$ \\
\hline & \multicolumn{7}{|c|}{ Metric Tons } \\
\hline $2001-2$ & 106,620 & 0 & 0 & 0 & 106,620 & 106,060 & 560 \\
\hline $2002-3$ & 430,332 & 0 & 0 & 41,500 & 471,822 & 428,602 & 1,720 \\
\hline $2003-4$ & $1,118,293$ & 0 & 0 & 0 & $1,118,293$ & $1,088,218$ & 30,075 \\
\hline $2004-5$ & $1,407,900$ & 0 & 157,270 & 0 & $1,565,170$ & $1,516,370$ & 48,800 \\
\hline $2005-6$ & $1,413,994$ & 0 & 91,165 & 0 & $1,505,159$ & $1,409,492$ & 95,667 \\
\hline $2006-7$ & $1,725,526$ & 0 & $1,096,995$ & 390,973 & $3,213,494$ & $1,929,938$ & $1,283,556$ \\
\hline $2007-8$ & $2,777,826$ & 786,672 & $3,045,995$ & $1,106,127$ & $7,716,620$ & $5,111,607$ & $2,605,013$ \\
\hline $2008-9$ & $3,148,306$ & 634,455 & $6,061,035$ & 908,690 & $10,752,486$ & $6,989,136$ & $3,763,351$ \\
\hline $2009-10$ & $4,013,671$ & 722,967 & $5,637,163$ & 283,436 & $10,657,235$ & $6,960,854$ & $3,696,382$ \\
\hline $2010-11$ & $4,725,165$ & 590,104 & $3,910,675$ & 200,169 & $9,426,112$ & $6,686,824$ & $2,739,284$ \\
\hline $2011-12$ & $1,804,581$ & 253,118 & $1,134,698$ & 0 & $3,192,397$ & $2,377,013$ & 815,384 \\
\hline
\end{tabular}

Three patterns can be discerned by looking at the table above.

- From 2001-2 with a minor exception, all the cement exported went to Afghanistan

- 2007-8 was the first year that exports commenced with India

- Although North Zone still has a lead in exports, South Zone is also emerging as exporter of cement and clinker

\section{Lucky Cement Limited}

Lucky Cement has emerged as a favorite of investors at Karachi Stock Exchange. While most of the cement companies have gone though the proverbial cyclical ups and downs of peculiar to the cement industry, Lucky has continued to outperform its peers. It is poised to become a performer on the international theatre. It has started building a facility in the Democratic Republic of Congo to serve the fast growing African market. Our study however, concentrates on their performance in the South Asian market.

Lucky Cement Limited as one of the leading manufacturer therefore decided to build a facility in the south to:

Meet the growing needs of the southern part of the country, and

To export the surplus to the Middle East, Africa and South Asia.

\section{Lucky Cement's Karachi Plant}

The management at Lucky believed that the south zone of the country demands more cement and clinker than was currently made in 2005 . At that time, the projected installed capacity of the country was expected to be at 45 million tons by the year 2012. One third of it i.e. 15 million tons was estimated to be in the south. This meant that from that level of 6.8 million tons, another 8.2 million were to be added. That implied that even if the Dewan's Dhabeji and Al-Abbas group 
projects under construction at that time) were able to add 2- 3 million tons, the gap of about 4-5 million tons was still to be there to be filled by new projects. That was the basis of their plan of setting up a one million ton capacity plant in the south.

The management of Lucky Cement saw a clear advantage in building a cement plant in the South Zone. The advantages of a South Zone plant were:

- $\quad$ Proximity to a large expanding market that was adding major infrastructure such as the Lyari Expressway, the Gwadar Port, the Makran Coastal Highway, and major residential and commercial building in Karachi and Hyderabad.

- Proximity of the two ports in Karachi to bring cheaper (lower freight) coal as fuel Availability of the port near to the production facility to export the surplus

\section{Search for a Cheaper Fuel.}

Initially, the cement manufacturers in Pakistan used furnace oil as fuel in the burning process and as supplier of energy to run the plant. Gradually, the price of furnace oil became extremely high leading the manufacturers to look for a cheaper alternative. The table below shows a comparison of cost for furnace oil and coal as a source of fuel in cement manufacturing ${ }^{5}$ :

Table - 4

\begin{tabular}{|r|c|c|r|r|}
\hline & Furnace Oil & Imported Coal & Exchange Rate & Imported Coal \\
\hline Financial Year & Rs. Per Ton & US\$ Per Ton & 1 US\$ & Rs. Per Ton \\
\hline $2010-2011$ & 47,317 & 108.2 & 86.0 & $9,307.36$ \\
\hline $2009-2010$ & 39,137 & 75.9 & 85.5 & $6,489.45$ \\
\hline $2008-2009$ & 33,910 & 94.9 & 81.4 & $7,724.86$ \\
\hline $2007-2008$ & 31,444 & 94.5 & 68.3 & $6,454.35$ \\
\hline $2006-2007$ & 20,107 & 51.7 & 60.4 & $3,122.68$ \\
\hline $2005-2006$ & 20,300 & 48.0 & 60.2 & $2,889.60$ \\
\hline $2004-2005$ & 13,331 & 53.7 & 59.6 & $3,200.52$ \\
\hline $2003-2004$ & 11,282 & 42.2 & 57.9 & $2,443.38$ \\
\hline
\end{tabular}

Coal therefore has a clear advantage over furnace oil. Lucky Management after deciding to use coal as their choice of fuel embarked upon receiving a steady and reliable supply of coal.

Their first choice was Lakhra coal. It has the advantage of abundance in supply and very close to the production facility. It was also much cheaper than the furnace oil. Lakhra coal, however, had a serious flaw:

Furnace Oil:

Approximate furnace oil required per ton

Sulfur content - furnace oil

$85 \mathrm{Kg}$

$3.5 \%$ (Avg.) 
Sulfur induced per ton of clinker (85 x $3.5 \%)$

Lakhra Coal:

Requirement of Lakhra coal per ton of clinker

Sulfur content - Lakhra coal

Sulfur induced per ton of clinker
$2.97 \mathrm{Kg}$

$223 \mathrm{Kg}$

$5.49 \%$ (Avg.)

$12.24 \mathrm{Kg}$

From the above data we see that by using Lakhra coal instead of furnace oil the sulfur content in clinker rises by almost 300 percent. This is a major hurdle for industries to shift to coal from furnace oil. The cost of production is higher and the quality of clinker is worse, which deteriorates the quality of cement. Additionally, Lakhra coal also has high volatile matter which gives rise to spontaneous combustion problems.

The Management therefore decided to use coal imported from Indonesia to use as fuel for production. In 2005 the FOB price of Indonesian coal was US\$42 per ton. Freight from Indonesia to Karachi was US\$20 per ton. Even with an unfavorable exchange rate of US\$1 to Rs. 60 , the Indonesian coal gave the company a clear advantage over furnace oil.

\section{Profitability}

Lucky Cement has delivered a consistent profitable performance over a long period of time. Table 2 above shows that with the exception of financial years between 2003-2006, the cement industry has not been a very profitable business. Comparably Lucky Cement has delivered profits consistently over a long period of time. The table below shows their revenue, expenses and profit from 2006 to $2011^{6}$ :

Table -5

\begin{tabular}{|l|c|c|c|c|c|c|}
\hline & 2006 & 2007 & 2008 & 2009 & 2010 & 2011 \\
\hline Sales & $8,054,101$ & $12,521,861$ & $16,957,879$ & $26,330,404$ & $24,508,793$ & $26,017,519$ \\
\hline $\begin{array}{l}\text { Cost of } \\
\text { sales }\end{array}$ & $\underline{5,073,797}$ & $\underline{8,846,708}$ & $\underline{12,600,706}$ & $\underline{16,519,138}$ & $\underline{16,529,932}$ & $\underline{17,306,400}$ \\
\hline $\begin{array}{l}\text { Gross } \\
\text { profit }\end{array}$ & $\underline{2,980,304}$ & $\underline{3,675,153}$ & $\underline{4,357,173}$ & $\underline{9,811,267}$ & $\underline{7,978,861}$ & $\underline{8,711,119}$ \\
\hline $\begin{array}{l}\text { Net } \\
\text { profit }\end{array}$ & $1,935,950$ & $2,547,292$ & $2,677,670$ & $4,596,549$ & $3,137,457$ & $3,970,400$ \\
\hline $\begin{array}{l}\text { Profit as } \\
\% \text { of } \\
\text { sales }\end{array}$ & $24 \%$ & $20 \%$ & $18 \%$ & $17 \%$ & $13 \%$ & $15 \%$ \\
\hline
\end{tabular}

\section{Export to South Asian Countries}

Armed with a cost advantage and enviable profitability, Lucky Cement management embarked upon looking for export markets in South Asia. They believed that due to their high growth potential and proximity to Pakistan, they can be a dependable and profitable market. India with above normal growth ranging from $8 \%$ to $10 \%$ during the years 2006 to $2010^{7}$ holds a high potential for cement exports. Sri Lanka, coming out of a long and disastrous civil war offers 
opportunities to contribute towards the repair and development of their physical infrastructure. It is estimated that cement demand will grow in India at an average rate of $9.8 \% \mathrm{t}$ for fiscal years 2011-2014 ${ }^{8}$. Not all this demand can be met with the Indian cement industry that is already facing high fuel and distribution costs. Indian cement industry came under pressure due to an $8.3 \%$ increase in freight and $12.6 \%$ increase in fuel and power costs in FY $11-12^{9}$.

\section{Going Global}

Although, Lucky Management has a long experience selling their products (clinker and cement) in Afghanistan and the Middle East, entering the South Asian market is a different ball game. The countries in the Indian subcontinent have trade policies that clearly favor their local industries. Cement being a base commodity is a highly controlled item. South Asian countries (including Pakistan) jealously guard their cement markets to prevent foreign incursion. Lucky Management foresaw the following advantages in entering the South Asian markets:

- Their large customer base and huge development potential

- Diversification of their export market from two countries namely, Afghanistan and UAE, to many countries.

- $\quad$ Reduce their dependence on a very volatile local market.

- Proximity of the South Asian markets to their production base in the South Zone.

Lucky Management used the classical textbook approach to enter South Asian markets. They are using a step by step process to enter the market and sell their product. The steps are ${ }^{10}$ :

- No regular export activities

- Export via independent representatives

- Establishment of one or more subsidiaries

- Establishment of production facilities abroad

\section{Opening Doors in India and Sri Lanka}

Lucky Cement was fortunate to have exporting doors opened for them by the importing countries themselves. In case of India, one of the largest trading houses asked Lucky to dispatch their product to them. This trading house was influential enough to process all the import requirements itself on the Indian side for Lucky to ship their consignment. For Sri Lanka, it was one of their ministers who personally requested Lucky to export cement to his country. Lucky management used this opportunity to introduce their product and their name to other importers in the country. Starting with small consignments of a few thousand tons, Lucky is now shipping cement and clinker to these countries in hundred of thousands of tons every year.

Impediments to Exports both India and Sri Lanka have strong organizations to verify the quality of cement and clinker imported in their country. In India the task of verification of quality and issuance of a clearance certificate is performed by the Bureau of Indian Standards (BIS) while in Sri Lanka, Sri Lanka Standard Institute (SLSI) performs this job. In India a certificate issued to an exporting entity is valid for one to two years for all their shipments while in Sri Lanka, SLSI 
constantly test samples picked from shipments arriving at Colombo Port. Although primary role of these National Standards Bodies (NSBs) is to ensure that the cement being imported complies with relevant local Cement Standards but these often NSBs become a Non-Tariff Barriers for free trade.

On the face of it, it seems that it is easier to export to India than to Sri Lanka due to the duration of the validity of the certificate. However, Lucky found it from their experience that it was harder to get a certificate from BIS than to SLSI. The officials at BIS asked to come to Pakistan to inspect all the cement making plants who have requested to have quality assurance certificate issued to them instead of confining themselves to each shipment. Towards the end of 2010 BIS Certificates of Lucky Cement Karachi Plant and certificates of most of other cement exporters to India expired. Despite Pakistani cement industry's persistent follow-up with BIS directly as well as through government, the auditors of BIS finally came to Pakistan after 5-6 months i.e. March 2011. Additional time was required for getting clearance from Indian Interior Ministry. The team of auditors entered Pakistan through Wagah and then fanned out to entire Pakistan and inspected all factories to renew their permits. Once the certificate was given to Lucky they could export both cement and clinker to India for a whole year.

The SLSI also becomes NTB as it tests every single shipment. In Sri Lanka, even with the blessing of a minister, the bureaucracy played its hand by slowing down shipments from Pakistan. This was done on the behest of the local manufacturers who did not want competition for their products from Pakistan. The delay in issuing quality certificate pushed the delivery schedule forward causing the shipper to pay demurrage to the shipping company. It also happens that the test results obtained by SLSI in their Lab do not comply with SLSI Standard requirement. This issue is being addressed by picking parallel sample of all shipments reaching Sri Lanka sent to an accredited Laboratory in UK in addition to sample tested by SLSI. None of the sample ever tested in UK or any other accredited and independent Laboratory has been found unsatisfactory or non-complying with standards. However this adds to the expenses.

Fuel costs happen to contribute about $60 \%$ of the total cost of production. Cement being a high investment items also has a high fixed cost. With a high variable cost and high fixed cost, the profitability in cement business depends upon lowering fuel costs and working at a high capacity. Lucky needs to substitute the high priced coal for a low priced substitute and work at close to $100 \%$ capacity to stay competitive within the country and outside.

\section{Logistic Advantage in Shipment to South Asia}

Currently, the maritime trade is experiencing a slow down. With Europe facing recession, Asia has a huge build up of empty containers. The seaborne shipping business itself is feeling the pinch. Maritime freights are down and availability of both container and bulk ships is high. This is helping Lucky to ship their products to both India and Sri Lanka at competitive rates. Even within India, due to high business activity, both surface and maritime freights have increased. India also has a rundown infrastructure (it has no motorways to speak of) causing transport costs to go up. Cement sent from surplus states such as Gujrat may not be price competitive when it reaches the southwestern state such as Kerala after factoring in the transportation costs. Lucky Management is exploiting this costs difference to their advantage. Karachi Plant's proximity to Port really helps in 
keeping inland freight low. All other major players in Pakistani cement industry are located in North Zone and they incur substantial inland freight to bring their cement to Karachi port. Lucky Cement is the only company in Pakistan having its own set-up of bulker fleet as well as loose cement silos at Karachi ports. In cement distance of market from production unit really makes difference. With Lucky's Nooriabad Plant working at near full capacity, they are able to dispatch both cement and clinker at competitive prices to both India and Sri Lanka. They should therefore look for long-term cost advantages such as increased productivity and substitution of high priced coal to a cheaper fuel.

Traditional commodities traded between Sri Lanka and Pakistan is tea and rice. Pakistan exports rice to Sri Lanka and Sri Lanka exports tea to Pakistan. Rice is also exported in containers so when export of Rice is at peak, the availability of containers for cement exports becomes a problem. This also results in increase in ocean freight by shipping lines.

Even with logistical and bureaucratic impediments, Lucky managed to increase its shipment to South Asia. Below is a record of quarterly shipment of cement to both India and Sri Lanka* for the last two fiscal years: (fiscal 2011-2012, three quarters only)

\begin{tabular}{|l|c|r|r|r|r|}
\hline \multicolumn{1}{|c|}{$\mathbf{2 0 1 0 - 1 1}$} & $\mathbf{1}^{\text {st }}$ Quarter & $\mathbf{2}^{\text {nd }}$ Quarter & $\mathbf{3}^{\text {rd }}$ Quarter & 4th Quarter & \multicolumn{1}{c|}{ Total } \\
\hline India & 308 & 5,570 & 38,472 & 26,600 & 70,950 \\
\hline Sri Lanka & 291,261 & 69,487 & 65,545 & 107,363 & 533,655 \\
\hline Total & 291,569 & 75,057 & 104,017 & 133,963 & 604,605 \\
\hline 2011-12 & $\mathbf{1}^{\text {st }}$ Quarter & $\mathbf{2}^{\text {nd }}$ Quarter & $\mathbf{3}^{\text {rd }}$ Quarter & 4th Quarter & Total \\
\hline India & 23,716 & 10,416 & 9,100 & NA & 43,232 \\
\hline Sri Lanka & 56,178 & 78,458 & 180,682 & NA & 315,318 \\
\hline Total & 79,894 & 88,874 & 189,782 & NA & 358,550 \\
\hline
\end{tabular}

*Internal company reports

\section{Future Opportunities and Challenges}

Lucky has embarked upon an ambitious plan to export to South Asia and Africa. They already have a strong presence in Afghanistan and UAE. However, doing business in South Asia carries its own risks and rewards. Both India and Sri Lanka are expected to grow with a rapid pace in the coming years. India is expected to maintain its double digit GDP growth. It did not spend enough to build and, maintain its physical infrastructure. Government of India (GOI)'s Eleventh Five-Year Plan recognizes this deficiency and has allocated USD 160 billion to be spent on developing logistic infrastructure. This amount is a full $2.3 \%$ of $\mathrm{GDP}^{11}$. According to McKinsey, this amount though large enough is in sufficient to redress the situation. They estimate the proposed expenditure to be over UDS 500 billion. Anything less will result in India suffering economic losses of about USD 120 billion annually by year 2020 .

McKinsey is proposing that GoI should redirect the USD200 billion investments on roads. This money should be used in developing and expanding the high density corridors, lengthening the existing national highways. They also propose to build 15 expressways by the year 2020 to address the rapidly increasing freight traffic ${ }^{12}$. 
Sri Lanka is coming out of a very long and destructive civil war. Its North stands in ruin and needs to be rebuilt, some part actually from scratch. It requires a tremendous amount of capital to develop its infrastructure. Sri Lanka being a tourist heaven cannot afford to have a slow rate of infrastructure development. Both these countries offer Lucky tremendous opportunities for export of cement and clinker.

Sri Lanka had an extensive roadway system to meet its need at the times of its independence. However, during the civil war, due to changing priorities and redirection of resources, the road infrastructure fell into disrepair. According to a World Bank report the country is facing logistic infrastructure problems that are affecting the growth of its tourism and commerce ${ }^{13}$ :

- National highways, which are mostly two-lane, are unable to carry the current volume of mixed traffic (pedestrians, bikes, bullock-pulled-vehicles and motor vehicles). This, together with the lack of side lanes and paved shoulders, leads to uncontrolled development of roadsides and causes low travel speeds, poor level of service, and less long-distance traffic.

- Neglected maintenance, as well as the lack of official capacity and resources, has led to the severe deterioration of roads. This adversely affects farmers taking produce to markets and villagers travelling to cities to reach social services.

- Urban streets are in poor condition due to flooding, blocked drains, heavy traffic, and low quality construction. The lack of drainage poses a serious threat to traffic in congested areas, affects people's health, and hampers the development of commerce and tourism.

The Government of Sri Lanka has planned to spend USD 6 billion to repair old road and build new highways and expressways to solve the transportation problems highlighted in the above World Bank report. This expenditure is on top of what the Government intends to spend in developing repairing and developing the areas devastated by the civil war.

Both India and Sri Lanka therefore offer great opportunities for Lucky Cement to carve a market for them. In both the countries, the bureaucracy is extremely strong and it finds ways to help their favorite sons. Lucky will have to stay one step ahead of the game in both India and Sri Lanka to achieve its goal of becoming a major exporter of their product to South Asian countries. 莯料

\section{References:}

http:/www.pakistaneconomist.com/database2/cover/c96-97.asp

http://www.apcma.com/data_productioncapacity.html

http://www.apcma.com/cost_profit.html

http://www.apcma.com/data_export.html 
https://ir.iba.edu.pk/businessreview/vol8/iss1/11

DOI: https://doi.org/10.54784/1990-6587.1222

Business Review - Volume 8 Number 1

http://www.apcma.com/cost_prices.html

Lucky Cement Limited - Annual Reports FY 2006-2011

International Monetary Fund

http://www.bharatbook.com/detail.asp?id=40518

http://www.bharatbook.com/detail.asp?id=40518

Kotler and Keller, Marketing Management (Prentice -Hall of India Private Limited, New Delhi$110001), 12^{\text {th }}$ Edition, page 670 .

http://www.mckinsey.com/locations/india/mckinseyonindia/pdf/Logistics_Infrastructureby2020_f ullreport.pdf - p.13.

Ibid.p.16http://web.worldbank.org/WBSITE/EXTERNAL/COUNTRIES/SOUTHASIAEXT/EXT

SARREGTOPTRANSPORT/0,,contentMDK:20699037 menuPK:869140 pagePK:34004173 pi

PK:34003707 theSitePK:579598,00.html

"Few people attain great lives in large part because it is just so easy to settle for good life. The vast majority of companies never become great, precisely because the vast majority becomes quite good. And that is their main problem."

- Jim Collins in Good to Great 